\title{
Study of Halophytes Dispersion in the North-West Region of Algeria
}

\author{
Chahrazed Hassaine1, Rédda Aboura1, Abdessamad Merzouk ${ }^{1 *}$, Djamel Benmansour ${ }^{2}$ \\ ${ }^{1}$ Laboratory of Ecology and Natural Ecosystems Management, Faculty of SNV_STU, University of Tlemcen, \\ Tlemcen, Algeria \\ ${ }^{2}$ Laboratory of Statistics and Random Modeling, University of Tlemcen, Tlemcen, Algeria \\ Email: ${ }^{*}$ as merzouk@yahoo.fr
}

Received 5 May 2014; revised 25 June 2014; accepted 2 July 2014

Copyright (C) 2014 by authors and Scientific Research Publishing Inc.

This work is licensed under the Creative Commons Attribution International License (CC BY).

http://creativecommons.org/licenses/by/4.0/

(c) (7) Open Access

\section{Abstract}

To know the mode of distribution of halophytes species in the western region of Algeria, it was considered useful to undertake a study based on the achievement of identified linear. Two areas were considered, Northern Tlemcen (Beni Saf and Rachgoun) and Northwest Oran (Sabkha). The trend of climate aridity which is more pronounced in the study area may have influences on floristic halophytes. The study of the floristic composition showed the importance of indicator halophitisation species such as Atriplex halimus, Tamarix gallica, Salicornia fruticosa, Arthrocnemum glaucum and was accompanied by various therophytes such as Sinapis arvensis, Erodium moschatum, Malva sylvestris and Plantago lagopus. ANOVA (analysis of variance) has highlighted the factors that influence the spatial distribution of some halophytes species at five stations studied; some are dispersed aggregates (Tamarix gallica, Suaeda fruticosa) with a coefficient of variation (Cv) greater than 10\%; others are regularly dispersed (Atriplex halimus) with a coefficient of variation (Cv) less than $10 \%$.

\section{Keywords}

West of Algeria, Halophytes, ANOVA, Dispersion

\section{Introduction}

It was confirmed long ago that climate change and anthrogenic actions have influenced the balance of different ecosystems, especially in the Mediterranean region, which has accelerated the phenomena of drought, erosion and soil degradation, and therefore degradation canopy [1]. Algeria has large saline areas spreading along the

*Corresponding author. 
coast and inland in the form of sabkha and chotts. This situation exacerbated by intense summer evaporation promotes the rise of salts on the surface. Our study area is characterized by halophyte vegetation, which extends along the banks of the Oued Tafna and Oued El-Malah, which will be compared to plants distributed around the Sabkha of Oran (El-Amria 1 and 2) having often different ecological conditions.

The vegetation of the region of Tlemcen has a good example of a study of plant diversity and above all an interesting synthesis of the natural ecosystem dynamics.

According to [2], any character in the physical and biotic environment is likely to affect the distribution of species in nature. Several studies have been conducted on the distribution of plant species including those [3]-[7]. Among the researchers who have studied plant ecology of halophytes include [8]-[12]: all these works have fueled the knowledge capital of the diversity and heterogeneity of vegetation halophytes. So in our case, will this work allow us to understand the structures and spatial distributions of halophytes and their ecological significance? To answer this question, we conducted a linear analysis allowing the identification of relationships between halophytes and their environments.

\section{Materials and Method}

\subsection{Sites and Choice of Stations (Figure 1)}

Our study area locates in the western part of North-West Algeria. The medium that we propose to study is shared between Tlemcen, Oran and Ain Témouchent, it is situated between $0^{\circ} 32^{\prime}$ and $02^{\circ}$ west longitude and $34^{\circ} 30^{\prime}$ and $35^{\circ} 49^{\prime}$ north latitude. It is naturally limited by the mountains of Traras northwest and the mountains of Mardjadjou north east and south by the mountains of Tessala. The choice of the number of 05 stations is still guided by the presence of halophytes, we selected two stations on the coast (Rachgoun, Beni Saf) and two on the edges of the Sabkha of Oran (El-Amria 1 and 2) and finally another intermediary, it is El-Malah station.

\subsection{Bioclimate}

To conduct a study of the action of climatic factors on the distribution of vegetation halophile in the study area, rainfall data and temperature were used to calculate the Q2 Emberger it will enable us to position our weather stations in bioclimatic zones. Extreme temperature values were used: "M" (average temperature of the hottest month) and "m" (mean temperature of the coldest month).

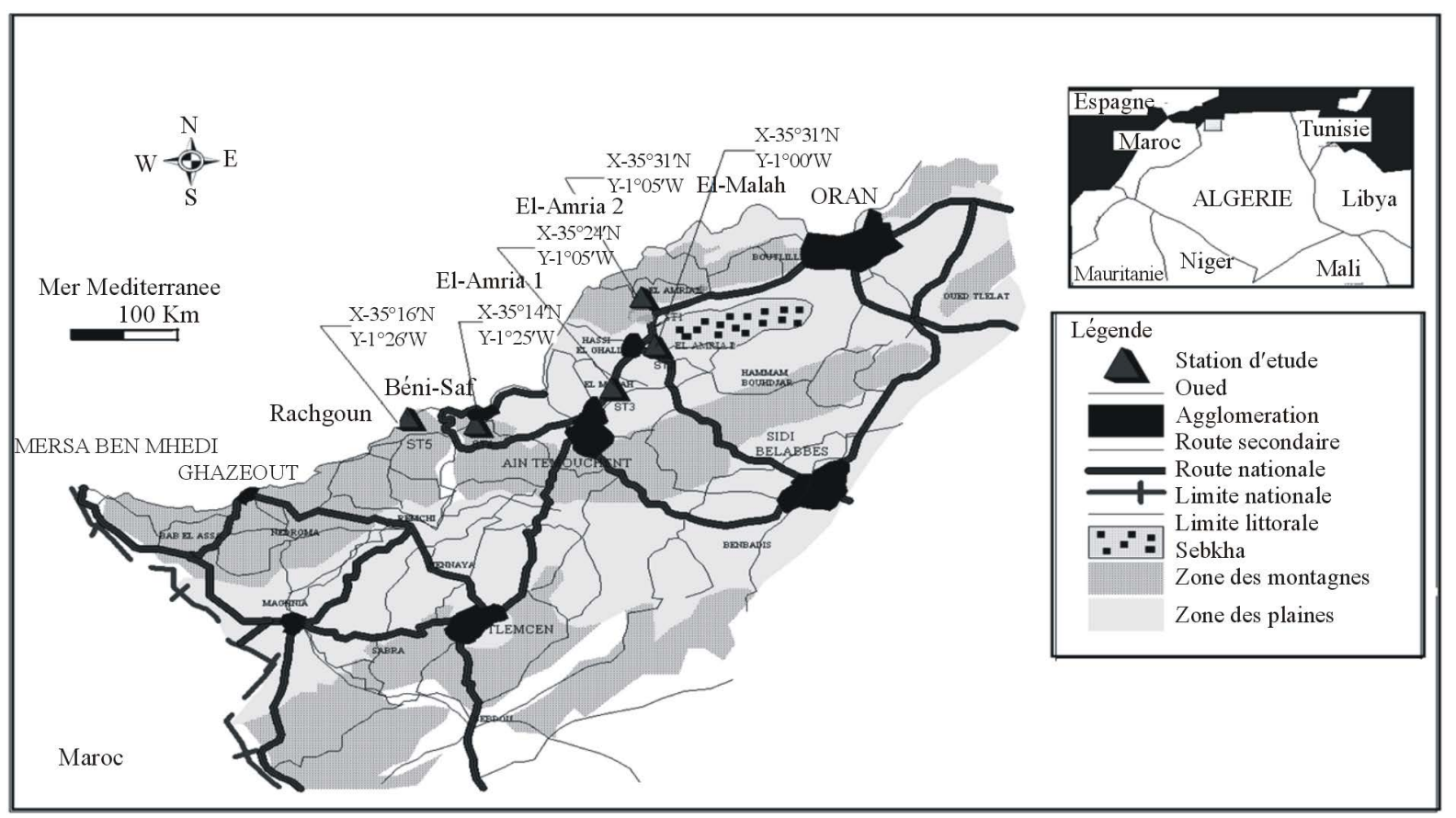

Figure 1. Location of study sites. 


\subsection{Floristic Surveys (Figure 2)}

The quantitative study of a species or community requires a method which is the result of a number of theoretical and practical choices. Linear density studies, recovery or frequency provide extremely valuable information for the analysis of the structure and homogeneity of the vegetation. You can push benefit analysis and note the order of succession of species along a line [2]. Our study focuses on the description of the distribution of halophytic vegetation from data collected in grids and transects adjacent plots; it allows the identification of relationships between plants and their environment [2]. The analysis is performed in the direction of the largest variation in the middle (along the salinity gradient), so a technique to obtain plots may translate the maximum ecological situations while being representative of the greatest number of cases.

The number of surveys and transects is selected based on the diversity of ecological factors, structures, vegetation type and stage of the evolution of the halophile vegetation. The linear analysis of the vegetation covers 10 transects per station $20 \mathrm{~m}$ long and $1 \mathrm{~m}$ wide, contiguous $50 \mathrm{~cm}$ on each side plots were identified, so we have 10 plots per transect and 100 readings per station. Transects were made by station variably spaced to be representative of a homogeneous area and also to show the continuity between the vegetation zones. The transect is shown by a measuring tape, and we denote the total length, direction, geographic coordinates taken using GPS. The model presence-absence has been applied for the five stations; the dispersion of different halophytes was analyzed. The harvested plants are determined using the new flora of Algeria [13], as well as the flora of Sahara [14].

\subsection{Statistics Tool}

Bouxin [15] offers a variety of methods for the analysis of the horizontal dispersion of plants. It aims to define at a transect if such dispersion is random, regular or clumped. In our case study we measured several transects per station and Bouxin [15] would require an analysis of dispersion transect detail at each study site, which may give conflicting results for a given change in a station here. Anova 1 the model associated with the Tukey test [16] was used as a statistical tool to analyze the dispersion of species at our study sites. Indeed, we reserve the ANOVA linear models where the explanatory variables are artificial variables taking the values 0 or 1 , indicating the presence or absence of an effect on a variable name.

In the case of regression, it is to evaluate the intensity of the effect of one variable while in the ANOVA, what concerns us is whether such a factor has an effect or not.

The ANOVA statistical technique is fundamental. It aims to compare averages over multiple samples and gives particular, in our case study, information on the spatial occupancy measured in the field 2 species. Tukey's test allows comparison averages pairs of samples measured. In this kind of study, it avoids confusion "distribution" and "dispersion". A variable has a distribution while organizations dispersion [17]. The dispersion analysis attempts to answer questions like:

- Individuals of species, attendance, abundance, biomass they are randomly dispersed, if they are not, are they catered so clumped or regular?
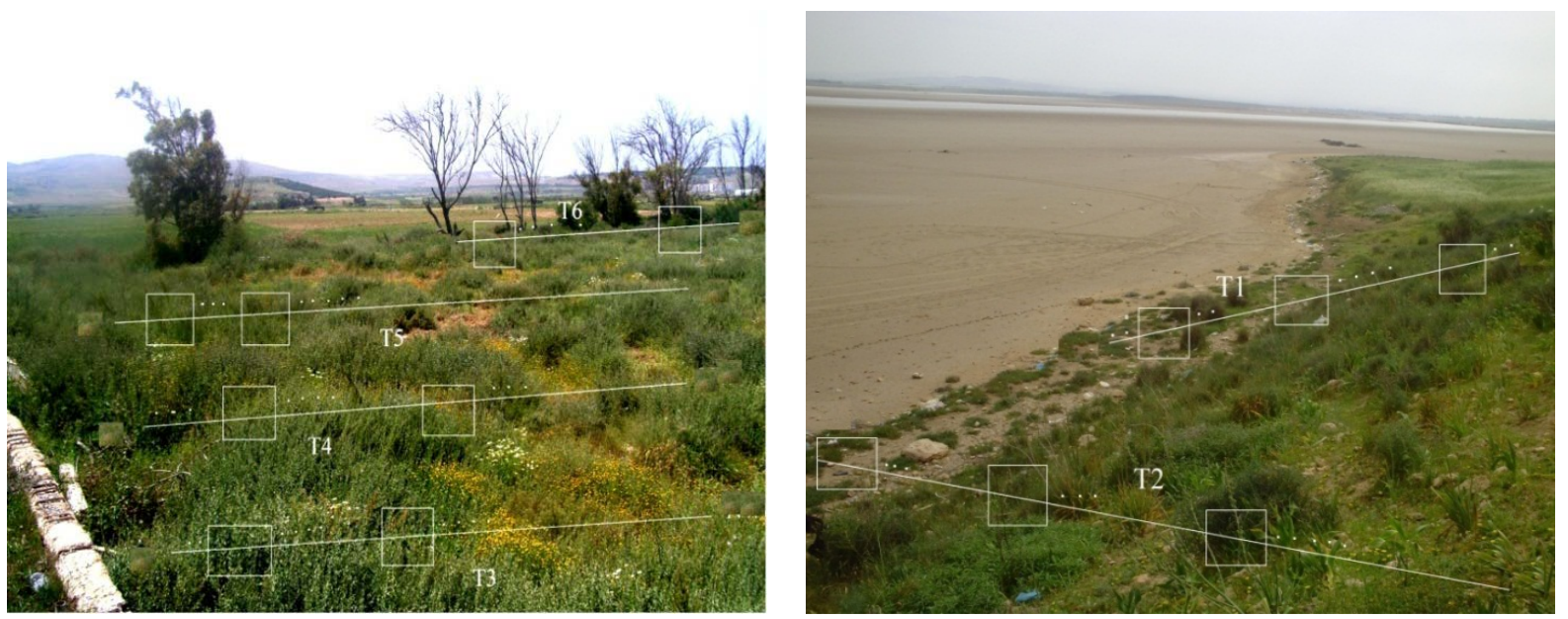

Figure 2. Transects measured in Stations of Rachgoun (right) and El-Amria 1 (left). 
- The same individuals are they scattered following patterns defined?

If the distribution of the species is random (random) in the community, the distribution of the number of individuals of the species in the plots of a given surface fits the law of fish. It follows that the mean value (m) of individuals in a plot tends to the variance $\sigma 2$. Following the work of [15] and [16], we say that the dispersion of a species:

- Random when the probability of encountering the species at any point of the surface is a priori the same everywhere.

- Aggregative (or contagious), when the probability of encountering the species is greater in some areas than others.

- Regular, when the presences of the species are dispersed more evenly than in the random dispersion.

\section{Results}

\subsection{Bioclimatic Aspects (Figure 3)}

According climagramme of Emberge resorts, Zenata and E-Senia, belong to the bioclimatic greater than temperate winter station Beni Saf semiarid lays in the semi-arid lower floor to warm winter. The trend of climate aridity, which is more pronounced in the study area, can have influences on the spatial distribution of halophytes in the region, a minority of plant species can adapt to these conditions. Moreover Franclet and Le Houerou [9] emphasize that Atriplex halimus is almost all bioclimatic zones, sub-humid, humid, arid, semi-arid Saharan upper and lower.

\subsection{Vegetation}

\section{Floristic Diversity}

\section{1) Station of Beni Saf}

The species found in this station are the number 73 transects. The first show dominance by the presence of halophytes Atriplex halimus, Tamarix gallica around the Oued Tafna followed by a floristic consisting essentially therophytes species whose presence is remarkable as Hordeum murinum, Avena sterilis, Erodium moschatum, Bromus rubens, Senecio vulgaris, Daucus carota. The transects on the heights of the station show the appearance of forest and meadow species scrub which confirms the relative plant diversity of this station. Among the species of these formations can be distinguished: Lavandula dentata, Whithania frutescens, Calycotome spinosa, Chamaerops humilis, Ampelodesma mauritanicum, and Asparagus acutifolius.

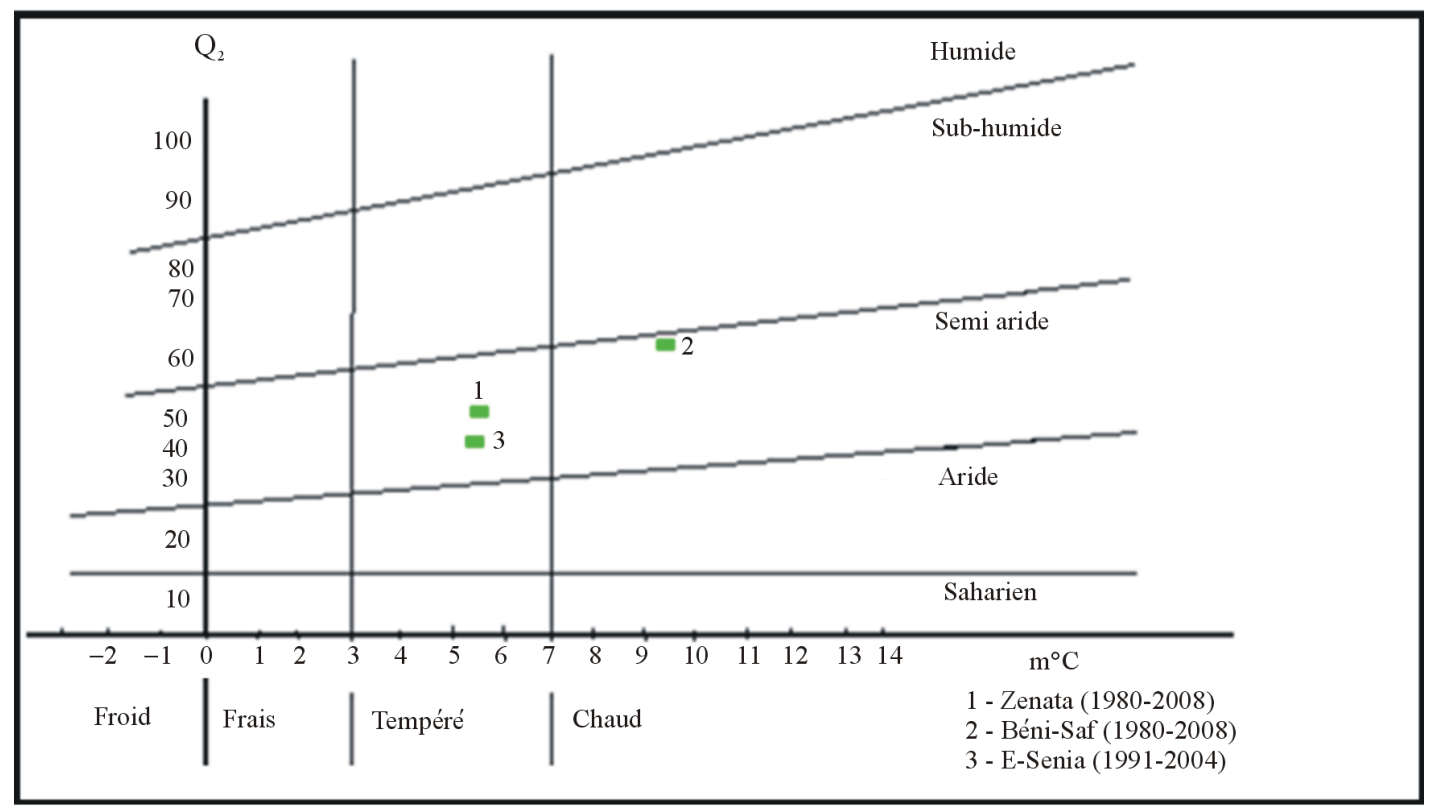

Figure 3. Bioclimate of the study area by Emberger's pluviothermic climagramme. 


\section{2) Station of Rachgoun}

This resort is dominated by halophytic species (Atriplex halimus, Tamarix gallica). 10 transects at this station show the sizeable presence of Atriplex halimus that installs in dense clumps and focus in colonies. These Atriplexaies occupy large areas grouped together with Tamarix on the bank of the Oued Tafna. The dominant species by their presence are: Atriplex halimus (89/100), Chenopodium album (51/100), Bromus rubens (51/100), Oxalis pes-caprae $(75 / 100)$.

\section{3) Station of El-Malah}

The floristic inventory in this resort includes 39 plant species including some transects are characterized by a strong presence of Atriplex halimus associated with Olea europea near the National Highway 22 connecting El-Malah and Ain Témouchent the one hand and mixed with Tamarix gallica along the Oued El-Malah other. Two examples illustrate this situation transects encountered in this station, it is the transects $(5,9)$, transects $(7$, 8, 10). Atriplex halimus, Tamarix gallica, Chenopodium album, Suaeda fruticosa form the core of halophytic species. 17 showed that the genus Tamarix gradually limit the width of rivers and wadis increasing sediment deposition. Moreover, it should also be noted the presence of good clumps of Atriplex halimus reaching two meters high at times. Frankenia thymifolia finds its optimum development between the tufts of Atriplex halimus.

\section{4) Station of El-Amria 1}

Plant communities at this station are organized in space according to a clear zonation at least generally disposed belts according to a salinity gradient. Transects 6 and 10 show that the edge of the Sabkha is dominated by vegetation that colonizes Arthrocnemum glaucum low salt and funds that grow in clumps forming small dense colonies spaced between which appear in summer blooms salts. That the highly soluble salts often accumulate in soils and arid climate in the shallows. They also appear as white blooms to the surface, when the texture and structure as the salts by capillary ascent. The floristic richness of this station is markedly different from the saltiest parts at low concentrations up areas.

\section{5) Station of El-Amria 2}

The vegetation of this station is highly anthropized and is essentially represented by Tamarix gallica which is distributed all along the transects (1 - 5) indicating that there is a training Tamarix gallica. Depending on the growing salinity gradient we could highlight species with high halophilie (Arthochemum glaucum, Salicornia fruticosa), the latter is strongly antropisée. The transects $(7,8.9)$ show the installation of other species such as Mesembryanthemum cristallinum, Mesembryanthemum nodiflorum and in the first few meters we can also note the abundance of Saueda fruticosa seems associates with Salicornia fruticosa (Transect 10). Other halophytes species are poorly represented by their presence, it is particularly Salsola vermiculata, Salsola sieberi, Halogeton sativus.

These perennials will settle in the lowest parts of depressions where evaporation mechanisms promote the development of efflorescence of gypsum and nitrate.

\subsection{Analysis of the Dispersion of Species}

\subsubsection{Station of Beni Saf (Table 1)}

The spatial distribution of individuals Tamarix gallica and Atriplex halimus at this station seems to be very heterogeneous $(\mathrm{P}$ value $=0)$ and highly dispersed at each transect measured (P-value indicating the significance level). Two groups A and B transects differ significantly by higher average attendance for group A and group B for low to Tamarix gallica and three groups A, B, C in the case of Atriplex halimus, with affinities between transects 5.7 and 8 . Certainly this is due to salinity (electrical conductivity) that varies from the slightly salty to salty. It is at its maximum throughout the Tafna River with $1.21 \mathrm{mS} / \mathrm{cm}$.

Indeed, the Table 1 below shows a high variability between the ten transects measured (average obtained at different transects a transect to another including Tamarix gallica and Atriplex halimus). Vegetation presented in this station shaped mosaics induces real nesting stands Tamarix gallica and Atriplex halimus which have different ecological affinities can make their often difficult to interpret. Chamaerops humilis while for the transect 4 is the only one to have a presence this species Lavandula multifida and the transect 2 is the only one to have a presence of this species.

The measured dispersion of both Lavandula multifida in the second transect and Chamaerops humilis in the fourth transect is contagious at this station. Indeed for the samples in which the mean is zero, we coefficient of variation $(\mathrm{CV})>10 \%$. Note that we observed in this station a little early contagion from these latter two species. 
Table 1. The group with Tukey’s method: BeniSaf.

\begin{tabular}{cccccccccccccccccc}
\hline \multicolumn{4}{c}{ Tamarix gallica } & \multicolumn{4}{c}{ Atriplex halimus } & \multicolumn{4}{c}{ Chamaerops humilis } & \multicolumn{4}{c}{ Lavandula multifida } \\
Transect & N & Average & Group & Transect & N & Average & Group & Transect & N & Average & Group & Transect & N & Average & Group \\
\hline 3 & 10 & 0.9000 & A & 2 & 10 & 1.0000 & A & 4 & 10 & 0.2000 & A & 2 & 10 & 0.5000 & A \\
1 & 10 & 0.9000 & A & 6 & 10 & 0.7000 & A B & 10 & 10 & 0.0000 & B & 10 & 10 & 0.0000 & B \\
9 & 10 & 0.7000 & A & 8 & 10 & 0.5000 & A B C & 9 & 10 & 0.0000 & B & 9 & 10 & 0.0000 & B \\
8 & 10 & 0.6000 & A & 7 & 10 & 0.5000 & A B C & 8 & 10 & 0.0000 & B & 8 & 10 & 0.0000 & B \\
7 & 10 & 0.1000 & B & 5 & 10 & 0.5000 & A & 7 & 10 & 0.0000 & B & 7 & 10 & 0.0000 & B \\
5 & 10 & 0.1000 & B & 9 & 10 & 0.3000 & B C & 6 & 10 & 0.0000 & B & 6 & 10 & 0.0000 & B \\
10 & 10 & 0.0000 & B & 4 & 10 & 0.2000 & B C & 5 & 10 & 0.0000 & B & 5 & 10 & 0.0000 & B \\
6 & 10 & 0.0000 & B & 10 & 10 & 0.0000 & C & 3 & 10 & 0.0000 & B & 4 & 10 & 0.0000 & B \\
4 & 10 & 0.0000 & B & 3 & 10 & 0.0000 & C & 2 & 10 & 0.0000 & B & 3 & 10 & 0.0000 & B \\
2 & 10 & 0.0000 & B & 1 & 10 & 0.0000 & C & 1 & 10 & 0.0000 & B & 1 & 10 & 0.0000 & B \\
\hline
\end{tabular}

\subsubsection{Station of Rachgoun (Table 2)}

The spatial distribution of Atriplex halimus at this station appears to be very homogeneous. There is a single group A and has a P value $=0.275$, and Atriplex halimus is distributed in batches and uniform. It adapts to different climatic conditions, that this species is found on almost all bioclimatic zones, the Mediterranean floor, sub-humid, humid, arid, semi-arid Saharan upper and lower.

The dispersion of Tamarix gallica shows two distinct groups A and B with a strong similarity between transects 6 and 7. This suggests an aggregative dispersion in dispersion at this station. This species has a strong root system and adapted to acquire water from groundwater or surface even in soils lacking moisture where it was reported that the water main root can reach a depth of $53 \mathrm{~m}$. The environmental conditions that allow the Tamarix develop a system of widespread and deep roots.

The spatial distribution of individuals of Chenopodium album and Suaeda fruticosa station at this dispersed manner appears to be contagious. This is due to the fact that these species still follow a salty environment strongly anthropic.

\subsubsection{Station of El-Malah (Table 3)}

The analysis of variance controlled on transects at this station factor, shows a regular distribution $(\sigma 2 \# 0)$ Atriplex halimus. We observe here the same group A. The observation of this species along all transects, perfectly reflects the ecological environmental conditions including edaphic factor, that Atriplex can grow on a gypso-calcaire crusting and grow sabloneux in soils and in particular silt. The spatial distribution of Suaeda fruticosa shows a pattern in its dispersion at most transects measured on this station $(\sigma 2 \# 0)$. Olea europea occupies only a small part of the available space in the transects at this station, the distribution of the number of individuals per transect follows the law of fish. These are individuals who create large heterogeneous conditions for smaller individuals 1. Strong distribution Tamarix gallica at transects 7 and 8 (groups A and B) measured on this station reveals an early contagion.

\subsubsection{Station of El Amria 1 (Table 4)}

The analysis of variance revealed a highly significant difference $(\mathrm{P}$-value $=0)$. This seems to result in a distribution of highly contagious Arthrocnemum glaucum trend, which has gradual changes in a given direction (at around the Sabkha). We are talking about no régional species whose presence depends little on climate but essentially very special soil conditions. 2 distributions Lygeum spartum and Suaeda fruticosa in this resort proves highly significant (P-value $=0$ ), the dispersion seems contagious in the station, it indicates the presence of an edaphic factor, it is silt, the Lygeum spartum is a species that colonizes silty-clay soils show that this perennial species invades sandy loam soils, indicate that Sparta tends to occupy silty clay and limestone soils. While Suaeda fruticosa always follows a highly salty environment anthropized.

Besides halophytes indicator species extreme environments (Sabkha), the presence of Chamaerops humilis was observed in two transects in this resort, including the spatial distribution is not significant $(\mathrm{P}$-value $=0.116$ ). This is a scrub marks advanced stage of degradation. 
Table 2. Information group with Tukey’s method: Rachgoun.

\begin{tabular}{cccccccccccccccccccc}
\hline \multicolumn{4}{c}{ Atriplex halimus } & \multicolumn{4}{c}{ Tamarix gallica } & \multicolumn{4}{c}{ Chenopodium album } & \multicolumn{5}{c}{ Suaeda fruticosa } \\
Transect & N & Average & Group & Transect & N & Average & Group & Transect & N & Average Group & Transect & N & Average & Group \\
\hline 10 & 10 & 1.0000 & A & 9 & 10 & 0.6000 & A & 9 & 10 & 1.0000 & A & 5 & 10 & 0.7000 & A \\
6 & 10 & 1.0000 & A & 2 & 10 & 0.6000 & A & 7 & 10 & 0.9000 & A & 3 & 10 & 0.5000 & A B \\
2 & 10 & 1.0000 & A & 7 & 10 & 0.4000 & A B & 2 & 10 & 0.8000 & A B & 8 & 10 & 0.4000 & A B C \\
1 & 10 & 1.0000 & A & 6 & 10 & 0.2000 & A B & 8 & 10 & 0.3000 & B C & 6 & 10 & 0.2000 & B C \\
8 & 10 & 0.9000 & A & 8 & 10 & 0.1000 & B & 6 & 10 & 0.3000 & B C & 4 & 10 & 0.2000 & B C \\
7 & 10 & 0.9000 & A & 10 & 10 & 0.0000 & B & 5 & 10 & 0.3000 & B C & 10 & 10 & 0.0000 & C \\
5 & 10 & 0.9000 & A & 5 & 10 & 0.0000 & B & 4 & 10 & 0.2000 & C & 9 & 10 & 0.0000 & C \\
9 & 10 & 0.8000 & A & 4 & 10 & 0.0000 & B & 3 & 10 & 0.2000 & C & 7 & 10 & 0.0000 & C \\
4 & 10 & 0.8000 & A & 3 & 10 & 0.0000 & B & 1 & 10 & 0.2000 & C & 2 & 10 & 0.0000 & C \\
3 & 10 & 0.7000 & A & 1 & 10 & 0.0000 & B & 10 & 10 & 0.0000 & C & 1 & 10 & 0.0000 & C \\
\hline
\end{tabular}

Table 3. Information group with Tukey’s method: El Malah.

\begin{tabular}{ccccccccccccccccccccc}
\hline \multicolumn{1}{c}{ Atriplex halimus } & \multicolumn{1}{c}{ Tamarix gallica } & \multicolumn{3}{c}{ Olea europea } & \multicolumn{5}{c}{ Suaeda fruticosa } \\
\hline Transect & N & Average & Group & Transect & N & Average & Group & Transect & N & Average Group & Transect & N & Average & Group \\
\hline 10 & 10 & 1.0000 & A & 8 & 10 & 1.0000 & A & 9 & 10 & 0.7000 & A & 6 & 10 & 0.6000 & A \\
7 & 10 & 1.0000 & A & 7 & 10 & 0.6000 & B & 5 & 10 & 0.5000 & A & 1 & 10 & 0.6000 & A \\
4 & 10 & 1.0000 & A & 10 & 10 & 0.2000 & C & 10 & 10 & 0.0000 & B & 4 & 10 & 0.5000 & A B \\
3 & 10 & 1.0000 & A & 9 & 10 & 0.0000 & C & 8 & 10 & 0.0000 & B & 10 & 10 & 0.4000 & A B \\
2 & 10 & 1.0000 & A & 6 & 10 & 0.0000 & C & 7 & 10 & 0.0000 & B & 3 & 10 & 0.2000 & A B \\
6 & 10 & 0.9000 & A & 5 & 10 & 0.0000 & C & 6 & 10 & 0.0000 & B & 2 & 10 & 0.2000 & A B \\
5 & 10 & 0.8000 & A & 4 & 10 & 0.0000 & C & 4 & 10 & 0.0000 & B & 9 & 10 & 0.0000 & B \\
1 & 10 & 0.8000 & A & 3 & 10 & 0.0000 & C & 3 & 10 & 0.0000 & B & 8 & 10 & 0.0000 & B \\
9 & 10 & 0.7000 & A & 2 & 10 & 0.0000 & C & 2 & 10 & 0.0000 & B & 7 & 10 & 0.0000 & B \\
8 & 10 & 0.6000 & A & 1 & 10 & 0.0000 & C & 1 & 10 & 0.0000 & B & 5 & 9 & 0.0000 & B \\
\hline
\end{tabular}

Table 4. Information group with Tukey’s method: El-Amria 1.

\begin{tabular}{|c|c|c|c|c|c|c|c|c|c|c|c|c|c|c|c|}
\hline \multicolumn{4}{|c|}{ Arthrocnemum glaucum } & \multicolumn{4}{|c|}{ Lygeum spartum } & \multicolumn{4}{|c|}{ Suaeda fruticosa } & \multicolumn{4}{|c|}{ Chamaerops humilis } \\
\hline Transect & $\mathrm{N}$ & Average & Group & Transect & $\mathrm{N}$ & Average & Group & Transect & $\mathrm{N}$ & Average & Group & Transect & $\mathrm{N}$ & Average & Group \\
\hline 10 & 10 & 1.0000 & A & 4 & 10 & 0.9000 & A & 6 & 10 & 0.9000 & A & 3 & 10 & 0.2000 & A \\
\hline 6 & 10 & 1.0000 & A & 8 & 10 & 0.5000 & A B & 10 & 10 & 0.7000 & A B & 2 & 10 & 0.1000 & A \\
\hline 9 & 10 & 0.4000 & B & 2 & 10 & 0.4000 & A & 9 & 10 & 0.5000 & A B & 10 & 10 & 0.0000 & A \\
\hline 5 & 10 & 0.2000 & B & 1 & 10 & 0.4000 & A B & 7 & 10 & 0.4000 & A B & 9 & 10 & 0.0000 & A \\
\hline 1 & 10 & 0.2000 & B & 7 & 10 & 0.2000 & B & 8 & 10 & 0.2000 & B & 8 & 10 & 0.0000 & A \\
\hline 8 & 10 & 0.1000 & B & 5 & 10 & 0.2000 & B & 5 & 10 & 0.2000 & B & 7 & 10 & 0.0000 & A \\
\hline 7 & 10 & 0.1000 & B & 10 & 10 & 0.1000 & B & 4 & 10 & 0.2000 & B & 6 & 10 & 0.0000 & A \\
\hline 4 & 10 & 0.1000 & B & 6 & 10 & 0.1000 & B & 3 & 10 & 0.2000 & B & 5 & 10 & 0.0000 & A \\
\hline 3 & 10 & 0.1000 & B & 9 & 10 & 0.0000 & B & 2 & 10 & 0.2000 & B & 4 & 10 & 0.0000 & A \\
\hline 2 & 10 & 0.1000 & B & 3 & 10 & 0.0000 & B & 1 & 10 & 0.2000 & B & 1 & 10 & 0.0000 & A \\
\hline
\end{tabular}




\subsubsection{Station of El-Amria 2 (Table 5)}

The presence of Tamarix gallica is greater in some places than others, she trained in aggregates. There are two distinct groups A and B with similarities between transects 1, 2 and 3. This species typically occupies sites in soil mixture of sand and silt or clay or silt and the sand and organic matter, the intermediate moisture, shallow groundwater, and little erosion. Variability Salicornia fruticosa in this resort proves highly significant (P-value $=0$ ), it is dispersed evenly over the 8.9 to 10 and non-existent elsewhere transects. We are witnessing the beginning of a contagion of this station by this species. This is due to some extent by the fact that the boundaries of distribution there of are determined by a high salinity and moisture confirms that this species settles sour wet and salty land... The distribution indicating a start of contagion Mesembryanthemum nodiflorum measured along transects in the resort of El Amria 2 shows the existence a wetland.

\subsection{Study of the Variation of the Dispersion between Stations for Some Salt Tolerant Species (Table 6)}

1) The analysis of variance of the spatial distribution for Arthrocnemum glaucum reveals a significant difference between the two stations (El-Amria 1, El-Amria 2) (P-value $=0.009)$. Tukey's test confirmed this difference in confidence level $=95.00 \%$, since zero is not in the confidence interval $[-0.2793,-0.0407]$. Groups to Arthrocnemum glaucum fall around the Sabkha, where the salinity is at its maximum, by forming a dense mat. This group is often very poor floristic see mono specific.

2) Comparisons dispersions Atriplex halimus show a very significant difference to the station of Beni Saf in relation to El-Malah and Rachgoun stations $(\mathrm{P}$-value $=0$ ). Tukey's test confirmed this difference in confidence level $=98.01 \%$, since zero is not in the respective confidence interval [0.3842, 0.6358] and [0.4042, 0.6558]. Reverse is recorded against a similarity between the stations and El-Malah, Rachgoun, confirming the installation of a halophilic atriplexaie which retains its character and covering half the surface covered by vegetation: $49.26 \%$.

3) The distribution of Salsola vermiculata at the El-Amria 1 and Amria Station 2 shows a significant difference $(\mathrm{P}$-value $=0.027)$. This species supports a higher dose of magnesian salts and forms (especially in the shallows) to heavy clay areas and containing a maximum of toxic salts. It disappears when the field is both compact and chlorinated.

4) Both El-Amria stations show a similarity to Suaeda fruticosa. Tukey's test confirming this similarity confidence level $=98.94 \%$, since zero is in the confidence interval $[-0.2227,0.1027]$. As for the El-Malah station, intervals respective trusts for the average differences being (CI: [ $-0.2806,0.0457]$ and CI: $[-0.2206,0.1057]$ ). Against by the diversity of this species showed a significant difference between El-Amria 1 and Rachgoun (CI: [-0.3327, -0.0073$])$. Suaeda fruticosa occupies licks clay soils covered by a thin sandy loam alluvial layer low in chlorides.

It features a frankly halophilic environment, including unsafe is increasing gradually and measure the cultivation, if no drainage work is done beforehand.

Table 5. Information group with Tukey’s method: El-Amria 2.

\begin{tabular}{ccccccccccccccccc}
\hline \multicolumn{4}{c}{ Tamarix gallica } & \multicolumn{4}{c}{ Salicornia fruticosa } & \multicolumn{4}{c}{ Suaeda fruticosa } & \multicolumn{4}{c}{ Mesembryanthemum nodiflorum } \\
\hline Transect & N & Average & Group & Transect & N & Average & Group & Transect & N & Average & Group & Transect & N & Average & Group \\
\hline 4 & 10 & 1.0000 & A & 10 & 10 & 0.7000 & A & 9 & 10 & 1.0000 & A & 7 & 10 & 0.5000 & A \\
6 & 10 & 0.8000 & A & 9 & 10 & 0.7000 & A & 8 & 10 & 0.8000 & A B & 10 & 10 & 0.1000 & B \\
5 & 10 & 0.8000 & A & 8 & 10 & 0.7000 & A & 10 & 10 & 0.7000 & A B & 9 & 10 & 0.1000 & B \\
3 & 10 & 0.5000 & A B & 7 & 10 & 0.0000 & B & 7 & 10 & 0.5000 & B C & 8 & 10 & 0.0000 & B \\
2 & 10 & 0.5000 & A B & 6 & 10 & 0.0000 & B & 5 & 10 & 0.1000 & C D & 6 & 10 & 0.0000 & B \\
1 & 10 & 0.5000 & A B & 5 & 10 & 0.0000 & B & 6 & 10 & 0.0000 & D & 5 & 10 & 0.0000 & B \\
10 & 10 & 0.2000 & B & 4 & 10 & 0.0000 & B & 4 & 10 & 0.0000 & D & 4 & 10 & 0.0000 & B \\
9 & 10 & 0.2000 & B & 3 & 10 & 0.0000 & B & 3 & 10 & 0.0000 & D & 3 & 10 & 0.0000 & B \\
8 & 10 & 0.0000 & B & 2 & 10 & 0.0000 & B & 2 & 10 & 0.0000 & D & 2 & 10 & 0.0000 & B \\
7 & 10 & 0.0000 & B & 1 & 10 & 0.0000 & B & 1 & 10 & 0.0000 & D & 1 & 10 & 0.0000 & B \\
\hline
\end{tabular}


Table 6. Analysis of dispersion between stations for some halophytes species.

\begin{tabular}{|c|c|}
\hline $\begin{array}{l}\text { Dispersion analysis of Arthrocnemumn glaucum between the stations of } \\
\text { El-Amria 1, El-Amria } 2 .\end{array}$ & $\begin{array}{l}\text { Trust Level }=95.00 \% \\
\text { Trust Gap IC: }[-0.2793,-0.0407]\end{array}$ \\
\hline $\begin{array}{l}\text { Dispersion analysis of Atriplex halimus between the stations of Béni-Saf, } \\
\text { El-Malah, Rachgoun. }\end{array}$ & $\begin{array}{l}\text { Individual Trust Level }=98.01 \% \\
\text { Station of Béni-Saf substructed from: } \\
\text { El-Malah [0.3842, } 0.6358] \\
\text { Rachgoun [0.4042, } 0.6558] \\
\text { Station of El-Malah substructed from: } \\
\text { Rachgoun }[-0.1058,0.1458]\end{array}$ \\
\hline $\begin{array}{l}\text { Dispersion analysis of Salsola vermiculata between the stations of } \\
\text { El-Amria 1, El-Amria } 2 .\end{array}$ & $\begin{array}{l}\text { Individual Trust Level }=95.00 \% \\
\text { Station of El-Amria } 1 \text { substructed from: } \\
\text { El-Amria } 2 \text { IC: }[0.0094,0.1506]\end{array}$ \\
\hline $\begin{array}{l}\text { Dispersion analysis of Suaeda fruticosa between the stations of El-Amria 1, } \\
\text { El-Amria 2, El-Malah, Rachgoun. }\end{array}$ & $\begin{array}{l}\text { Individual Trust Level }=98.94 \% \\
\text { Station of El-Amria } 1 \text { substructed from: } \\
\text { El-Amria } 2 \text { IC: }[-0.2227,0.1027] \\
\text { El-Malah IC: }[-0.2806,0.0457] \\
\text { Rachgoun IC: }[-0.3327,-0.0073] \\
\text { Station of El-Amria } 2 \text { substructed from: } \\
\text { El-Malah IC: }[-0.2206,0.1057] \\
\text { Rachgoun IC: }[-0.2727,0.0527] \\
\text { Station of El-Malah substructed from: } \\
\text { Station Rachgoun IC: }[-0.2157,0.1106]\end{array}$ \\
\hline $\begin{array}{l}\text { Dispersion analysis of Tamarix gallica between the stations of Béni-Saf, } \\
\text { El-Amria 2, El-Malah, Rachgoun. }\end{array}$ & $\begin{array}{l}\text { Individual Trust Level }=98.94 \% \\
\text { Station of Béni-Saf substructed from: } \\
\text { El-Amria 2 IC: }[-0.0401,0.2801] \\
\text { El-Malah IC: }[-0.3101,0.0101] \\
\text { Rachgoun IC: }[-0.3001,0.0201] \\
\text { Station of El-Amria } 2 \text { substructed from: } \\
\text { El-Malah IC: }[-0.4301,-0.1099] \\
\text { Rachgoun IC: }[-0.4201,-0.0999] \\
\text { Station of El-Malah substructed from: } \\
\text { Rachgoun IC: }[-0.1501,0.1701]\end{array}$ \\
\hline
\end{tabular}

5) The variability of Tamarix gallica appears very significant between these four stations. Tukey's test gives insignificant between Beni Saf, El-Amria 2, El-Malah and Rachgoun results, a significant difference between El-Amria 2 on one side and El-Malah and Rachgoun other hand (CI: $[-0.4301,-0.1099]$ and CI: [ -0.4201 , -0.0999]). Confirming its dispersion aggregates. By cons it is spread in the same way in the El-Malah and Rachgoun stations. Tamarix develops a strategy to produce seeds in abundance.

\section{Discussion and Conclusions}

Valleys, depressions, sebkhas chotts and the Saharan margins are likely to develop salt-tolerant vegetation character. A minority of plant species can adapt to these environments. There are annual halophytes species that germinate in the dry season when the water goes down below the soil surface as samphire (salicornia, arthrocnemum) and Poaceae salt-marsh resistant to both winter floods that pasture.

As a result of their location at precise rates of salinity, halophytes are divided into groups arranged in zones around savory continental depressions or along the seashore.

Our study showed that a number of species are organized according to the content of salts; the salinity of soils varies from $1.21 \mathrm{mS} / \mathrm{cm}$ to $1.35 \mathrm{mS} / \mathrm{cm}$. It concerns the areas around sebkha (El Amria 1 and El Amria 2), and depending on the salt content's decrease, strips more or less condensed in Arthrocnemum glaucum, Salicornia fruticosa then followed by a vegetation Suaeda fruticosa and Salsola vermiculata. Away towards the outside of the sabkha on mountain slopes, halophytes give a way to cover a representative training to scrub. Regarding the other stations (Beni Saf and Rachgoun), the floristic has a slight difference and reflects the aridity of the area by the presence of drought-tolerant species that have much in common, or at least live with halophytes. Halophytes oppose glycophytes, plants' unsalted media, for their close to those of xerophytes morphology (succulence stems or leaves, reduced leaf devices) and physiological traits: osmotic pressure, resistance to the nature and salt concentration; this faculty resistance often leads to the formation of vegetation belts characteristics. 
In the three stations Rachgoun, El-Malah and Beni Saf, the Atriplex communities present anthropogenic effects. At Rachgoune station, Asphodelus dominate compared to Atriplex. The anthropogenic impact suffering these eco-systems often induces a regressive dynamics which can lead to anthrophytisation.

The results of the analysis of variance show that halophytes species approximately consistent in their ecological constitution and their behavior against the main ecological factors of the resort, has a heterogeneous distribution within and between stations. The application of variance analysis (ANOVA) at one controlled factor made in transects of Beni Saf station shows a heterogeneous distribution of Tamarix gallica, Atriplex halimus, Lavandula multifida and Chamaerops humilis. This is explained by heterogeneity observed in this station that includes halophytes and matorrals species. In the station Rachgoun, the dispersion of halophytes species such as Tamarix gallica, Suaeda fruticosa and Chenopodium album, reveals very significant differences, against a regularity of occurrence of clumps of Atriplex halimus recorded. This confirms the presence of a homogeneous field Atriplexaie. The Atriplex halimus distribution, Tamarix gallica, Suaeda fruticosa, Olea europea, measured along transects El-Malah station gives significant differences. It is a diverse community that is subject to intense grazing pressure here. At the El-Amria 1, distributions of Arthrocnemum glaucum, Suaeda fruticosa, Chamaerops humilis, Urginea maritima, Lygeum spartum station show significant differences, and against similarity Chamaerops humilis is recorded between transects; this is translated by vertical variations of exogenous medium resulting from the coexistence of different species from environmental groups.

The case of perennial succulent halophytes (Arthrocnemum glaucum, Suaeda fruticosa) in opposition to the spring annual environmental groups (therophytes) develops in the surface more or less desalted by winter rains horizon. Highly significant differences in the distribution of species (Suaeda fruticosa, Tamarix gallica, Salicornia fruticosa, Mesembryanthemum nodiflorum) are observed in the El-Amria 2 station. This probably is explained by the intensive pastoral care which records that station.

Comparisons dispersions Atriplex halimus for station Beni Saf in relation to El-Malah and Rachgoun stations confirm the presence of edaphic and orographic factors (heterogeneity of soil, slope and exposure). However, a similarity is recorded between El-Malah and Rachgoune stations and this reflects the existence of an Atriplex community installing a slope and substrate that are like. The Atriplex communities of this coastal area show some heterogeneity that is due to both climate factor and the action of man.

The distribution of Salsola vermiculata at the El-Amria 1 and El-Amria 2 area stations shows a difference that is certainly the influence of edaphic factors (salinity). Suaeda fruticosa for differences in spatial distribution is obtained between the two groups of stations El-Amria 1, El-Amria 2 and El-Malah, Rachgoun while opposing. For cons, the two El-Amria stations (El-Malah, Rachgoun) show similarity on spatial occupancy of this species; this confirms the difference between the natural environment and coastal Sabkha Tamarix gallica has similarity in its distribution between El-Malah and Rachgoun stations that have the same natural environment- the presence of Oued Tafna and El-Malah. Tamarix is one of the most adapted to extreme environmental conditions species, and has a great ecological plasticity against the soil moisture where such suits flooded habitats and can be found in driest environments. It tolerates alkalinity where the $\mathrm{pH}$ exceeds the value of 8.5 and the electrical conductivity exceeds $50 \mu \mathrm{S} / \mathrm{cm}$. This species is found in river systems wadis, particularly of salt lakes, roadsides and railways and seasonal wetlands: mature plants can withstand long periods of flooding water (70 to 90 days and even 500 days) and other situations of mountains and arid deserts.

Floristic richness has no reason to be constant along the ecological environments; it is well known that certain extreme environments such as highly saline environments, Sabkha for example, have a very intense selection on the flora and vegetation consisting of species in very small numbers but often narrowly focused in these areas. Here for the indicator species, their presence is often few but generally very informative. IT is reported that the nature of the substrate (texture or fine), the microtopographic relief (channels, basin and sub-basin, dissected plateau), and the abundance of organic deposits (halonitrophilie) are factors of diversification that have a profound influence on the distribution of vegetation.

Some halophytes species are dispersed aggregates (Tamarix gallica, Suaeda fruticosa); others are regularly dispersed (Atriplex halimus). Some scientists state that the characteristics of the stations form, with the identity of their requirements, an association that accurately reflects the state of the local environment. As concerns the coastal zone and more accurately El-Malah, Beni Saf and Rachgoun stations, it is the anthropogenic factor that seems to be responsible for the distribution of taxa, while it is the edaphic factor which is responsible for this dispersion as to Sabkha region. The saline and sodic soils meet around large saline depressions: the sabkha and chotts in North Africa. It would be interesting in our opinion to continue this work by multiplying the number of 
studies and the number of contiguous plots that can enrich the biodiversity of halophytes species and their environments halomorphic stations.

\section{References}

[1] Benabadji, N. and Bouazza, N. (2000) Some Climate Changes Occurred in the South-West of Western Algeria. Journal of Renewable Energies, 3, 117-125.

[2] Gounot, M. (1969) Quantitative Vegetation Survey Methods. Masson Edition, Paris, 314.

[3] Long, G. (1958) Description of a Linear Method for the Study of the Evolution of Vegetation. Newsletter of Geographical Map, 2, 107-127.

[4] Thompson, H.R. (1958) The Statistical Study of Plant Distribution Patterns Using a Grid of Quadrats. Australian Journal of Botany, 6, 322-343. http://dx.doi.org/10.1071/BT9580322

[5] Warren Wilson, J. (1965) Point Quadrat Analysis of Foliage Distribution for Plants Growing Singly or in Rows. Australian Journal of Botany, 13, 405-409. http://dx.doi.org/10.1071/BT9650405

[6] Cox, G.C. (1987) Nearest-Neighbour Relationships of Overlapping Circles and the Dispersion Pattern of Desert Shrubs. Journal of Ecology, 75, 193-199. http://dx.doi.org/10.2307/2260544

[7] McDaniel, K.C. (2007) Salt Cedar Information. Department of Animal Range and Sciences, New Mexico State University, Las Cruces, 44.

[8] Djebaili, S. (1984) Algerian Steppe, Plant Sociology and Ecology. OPU, Algiers, 171.

[9] Franclet, A. and Le Houérou, H.N. (1971) The Atriplex in Tunisia and in North Africa. FAO, Rome, Document No. b0020, 189, 249.

[10] Billard J.P. and Binet, P. (1975) Physio-Ecology of Atriplex of Sandy Environments Coastlines. French Botanical Society, Aix-Marseille University, 439.

[11] Tremblin, G. (2000) Auto Ecological Behaviour of Halopeplis amplexicaulis: Pioneer Plant Sebkhas West Algerian. Drought Journal, 11, 9-16.

[12] Aboura, R. (2011) Contribution to the Study of Atriplex Ales in Western Algeria, Physiognomic and Phytodynamis Aspects. Doctorat Thesis, Plant Ecology, Tlemcen University, 156.

[13] Quezel, P. and Santa, S. (1962) New Flora of the Southern Algeria and Desert Regions. CNRS, Paris, 1170.

[14] Ozenda, P. (1977) Flora of the Sahara. 2éme Edition, CNRS, Paris, 662.

[15] Bouxin, G. (1974) Distribution of Species in the Herbaceous Layer at South Park Akagera National (Rwanda, Central Africa). Oecologia Plants Journal, 9, 315-332.

[16] Pielou, E.C. (1960) A Single Mechanism to Account for Regular, Random and Aggregated Populations. Journal of Ecology, 48, 575-584. http://dx.doi.org/10.2307/2257334

[17] Saporta, G. (2006) Probability and Statistical Data Analysis. Technical Edition. 


\section{Appendix}

\begin{tabular}{|c|c|c|c|c|}
\hline \multicolumn{5}{|c|}{ Inventoried species at study sites } \\
\hline Station de Béni-Saf & Station de Rachgoun & Station d'El-Malah & Station d’El-Amria 1 & Station d'El-Amria 2 \\
\hline Tamarix gallica & Atriplex halimus & Atriplex halimus & Suaeda fruticosa & Tamarix gallica \\
\hline Oxalis pescaprae & convolvulus althaeoides & Suaeda fruticosa & Salsola vermiculata & Daucus carota \\
\hline Silybum marianum & Sinapis arvensis & Hordeum murinum & Chrysanthemum coronarium & Atractylis cancellata \\
\hline Chrysanthemum coronarium & Erodium moschatum & Erodium moschatum & Lygeumspartum & Scolymus hispanicus \\
\hline Chenopodium album & Plantago lagopus & Cynaracardunculus & Asparagus stipularis & Hieracium pseudo-pilosella \\
\hline Calendula arvensis & Melilotus infesta & Daucus carota & Urginea maritima & Asteriscus maritimus \\
\hline Withaniafrutescens & Anagallis arvensis & Chrysanthemum grandiflorum & Asparagus albus & Hordeum murinum \\
\hline Rubia peregrina & Chenopodium album & Alopecurus bulbosus & Asteriscus maritimus & Chrysanthemum grandiflorum \\
\hline Hordeum murinum & Hordeum murinum & Bromus rubens & Asperula hirsuta & Malva sylvestris \\
\hline Sinapis arvensis & Daucus carota & Galium valantia & Brachypodium distachyum & Alopecurus bulbosus \\
\hline Daucus carota & Inula viscosa & Scorpiurus muricatus & Sileneconica & Plantago maritima \\
\hline Rumex tinginatus & Phalaris bulbosa & Anagallis arvensis & Lotus ornithopodioides & Brachypodium distachyum \\
\hline Phalaris bulbosa & Senecio vulgaris & Chrysanthemum coronarium & Lotus edulis & Bromus hordeaceus \\
\hline Galactite tomentosa & Scorpiurus muricatus & Bellis аппиа & Anthyllis tetraphylla & Bromus rubens \\
\hline Senecio vulgaris & Halopecurus bulbosus & Frankenia thymifolia & Calendula arvensis & Arthrocnemumglaucum \\
\hline Erodium muschatum & Bryonia dioica & Plantago albicans & Asphodelus microcarpus & Mesembryanthemum nodiflorum \\
\hline Allium roseum & Cupressus dupreziana & Senecio vulgaris & Aegilops ventricosa & Mesembryanthemum cristallinum \\
\hline Reichardiatingitana & Vicia sativa & Malva sylvestris & Sinapis arvensis & Stellaria media \\
\hline Scolymus grandiflorus & Chrysanthemum grandiflorum & Asperula arvensis & Plantago albicans & Atriplexglauca \\
\hline Carduus pycnocephalus & Chrysanthemum coronarium & Oxalis pes-carpae & Galium valantia & Peganum harmala \\
\hline Avena alba & Bromus rubens & Asteriscus maritimus & Plantago ovata & Salvia verbenaca \\
\hline Chrysanthemum grandiflorum & Echium vulgare & Linumstrictum & Hordeum murinum & Salsola vermiculata \\
\hline Asteriscus maritimus & Oxalis pes-caprae & Plantago lagopus & Phlomis herba-venti & Halogeton sativus \\
\hline Thapsia garganica & Tamarix galica & Inula viscosa & Gladiolus segetum & Salicornia fruticosa \\
\hline Reseda alba & Silybum marianum & Silybum marianum & Silene conica & Salsolasieberi \\
\hline Brachypodium distachyum & Taraxacumatlanticum & Scolymus hispanicus & Teucrium pseudo-chamaepitys & \\
\hline Echium vulgare & Withaniafrutescens & Marrubium vulgare & Chamaerops humilis & Chenopodium album \\
\hline Convolvulus althaeoides & Glyceria fluitans & Chenopodium album & Reseda alba & Chrysanthemum coronarium \\
\hline Halogeton sativus & Fumaria capreolata & Oleaeuropea & Alyssumscutigerum & Cynaracardunculus \\
\hline Salsolalongifolia & Raphanusraphanistrum & Melilotus infesta & Centaurea fragilis & Scorpiurus muricatus \\
\hline Lavandula multifida & Avena alba & Echinopsstrigosus & Mesembryanthemum nodiflorum & Frankenia laevis \\
\hline Lagurus ovatus & Medicagorugosa & Papaver rhoeas & Chrysanthemum grandiflorum & Beta macrocarpa \\
\hline Plantago albicans & Smyrnium olusatrum & Thapsia garganica & Senecio vulgaris & Suaeda fruticosa \\
\hline Bromus madritensis & Centaurea pullata & Beta macrocarpa & Torilis nodosa & \\
\hline Pallenis spinosa & Calendula arvensis & Sinapisarvensis & Catananche lutea & \\
\hline Bromus rubens & Suaeda fruticosa & Tamarix gallica & Asparagus acutifolius & \\
\hline Bellis silvestris & Avena sterilis & Ampelodesmamauritanicum & Bellis аппиа & \\
\hline Asphodelus microcarpus & Melilotus infesta & Bromuslanceolatus & Salvia prateinsis & \\
\hline Papaver rhoeas & Cichorium intybus & Onopordon acaule & Pallenis spinosa & \\
\hline Eryngium maritimum & Aegilops triuncialis & & Beta macrocarpa & \\
\hline Hedera helix & Scolymus hispanicus & & Thapsia garganica & \\
\hline Mentha longifolia & Salvia pratensis & & Daucus carota & \\
\hline Malva sylvestris & Bellis аппиа & & Bromusrubens & \\
\hline Lavendula dentata & Bellis silvestris & & Carthamuscaeruleus & \\
\hline Chamaerops humilis & Euphorbiasegetalis & & Anagallis arvensis & \\
\hline Lygeumspartum & Rumex tingitanus & & Convolvulus althaeoides & \\
\hline
\end{tabular}




\section{Continued}

\begin{tabular}{|c|c|c|}
\hline Artemisia herba-alba & Silybum marianum & Withaniafrutescens \\
\hline Stipa tortilis & Ampelodesmamauritanicum & Bryonia dioica \\
\hline Fagoniacretica & Buxussempervirens & Cynaracardunculus \\
\hline Salsola kali & Galium valantia & Salvia verbenaca \\
\hline Atriplex halimus & Carthamuscaeruleus & Frankenia thymifolia \\
\hline Echinopsspinosus & Phalaris paradoxa & Centaurea pullata \\
\hline Olea europea & Lolium multiflorum & Chenopodium album \\
\hline Gnaphaliumluteo-album & Hedera helix & Bellis silvestris \\
\hline Marrubium vulgare & Chenopodiumchenopodioides & Silybum marianum \\
\hline Fumanathymifolia & Echinopsspinosus & Olea europea \\
\hline Lobularia maritima & Malva sylvestris & Avena sterilis \\
\hline Ampelodesmamauritanicum & Rubia peregrina & Scorpiurus muricatus \\
\hline Astragalus lusitanicus & Thapsia garganica & Linumstrictum \\
\hline Ziziphus lotus & Galactites tomentosa & Cynoglossumcheirifolium \\
\hline Solenanthuslanatus & Atriplex littoralis & Sideritis montana \\
\hline Centaurea pullata & Pallenis spinosa & Malva sylvestris \\
\hline Plantago lagopus & Halimiumhalimifolium & Halocnemumstrobilaceum \\
\hline Bupleurum lancifolium & & Plantago lagopus \\
\hline \multicolumn{3}{|l|}{ Stellaria media } \\
\hline \multicolumn{3}{|l|}{ Borago officinalis } \\
\hline \multicolumn{3}{|l|}{ Urginea maritima } \\
\hline \multicolumn{3}{|l|}{ Asparagus stipularis } \\
\hline \multicolumn{3}{|l|}{ Asparagus acutifolius } \\
\hline \multicolumn{3}{|l|}{ Cirsium scabrum } \\
\hline \multicolumn{3}{|l|}{ Calycotomespinosa } \\
\hline \multicolumn{3}{|l|}{ Atriplexglauca } \\
\hline \multicolumn{3}{|l|}{ Anagallis arvensis } \\
\hline \multicolumn{3}{|l|}{ Salsolatetragona } \\
\hline \multicolumn{3}{|l|}{ Aizoom hispanicus } \\
\hline Ruta chalepensis & & \\
\hline
\end{tabular}


Scientific Research Publishing (SCIRP) is one of the largest Open Access journal publishers. It is currently publishing more than 200 open access, online, peer-reviewed journals covering a wide range of academic disciplines. SCIRP serves the worldwide academic communities and contributes to the progress and application of science with its publication.

Other selected journals from SCIRP are listed as below. Submit your manuscript to us via either submit@scirp.org or Online Submission Portal.
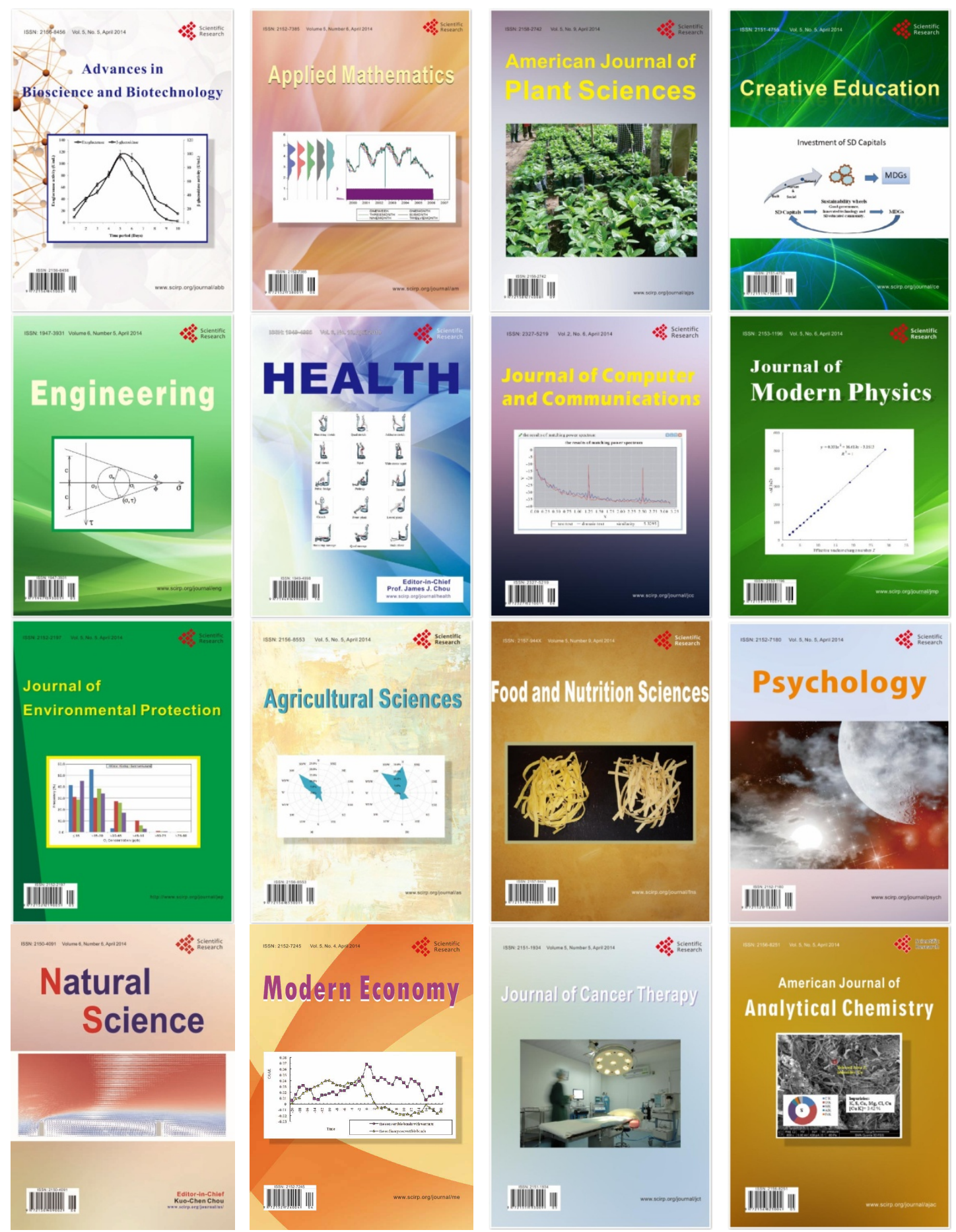